\title{
Optimization of RAPD-PCR Protocol to Screen Jatropha Curcas and Gossypium Hirsutum Grown in Metal Contaminated Soil
}

Narayanan Mathiyazhagan and Devarajan Natarajan*

Department of Biotechnology, Periyar University, Salem 636 011, Tamil Nadu, India

\begin{abstract}
The optimization of randomly amplified polymorphic DNA-polymerase chain reaction (RAPD-PCR) protocol was performed to screen two plants (Jatropha curcas \& Gossypium hirsutum) grown in metal contaminated soils. A CTAB method was employed for DNA extraction, but an overnight RNase treatment was carried out to eliminate RNA contaminants. The isolated DNA was used for RAPD-PCR amplification. The optimum condition for reliable amplification requires a higher concentration of $\mathrm{MgCl}_{2}(3 \mathrm{mM})$, primer $(2.5 \mu \mathrm{M})$, Taq DNA polymerase (1 unit) and $3 \mu \mathrm{l}$ of template DNA (sample) and an annealing temperature of $55^{\circ} \mathrm{C}$. Reproducible amplified products were observed in these conditions for both the plant species.
\end{abstract}

Keywords: Jatropha curcas; Gossypium hirsutum; DNA isolation; RAPD-PCR

\section{Introduction}

In India and elsewhere in the world there are several hectares of wet land that was polluted by industrial activities such as mining, metallurgical processing, textile production, tannery etc., but these areas are in demand for cultivation for crop production. To reclaim these contaminated soils plants are grown (phytoremediation). While the plants used for phytoremediation on contaminated soil do rehabilitate the site, there may be a chance for changes in their DNA due to metal stress. This needs to be characterized, but there are few problems encountered during isolation and amplification of DNA from plants grown in metal contaminated sites. The metals could interfere with Taq DNA polymerase during amplification. Plants grown in this environment could contain inhibitory metabolites. Moreover, the contaminating RNA that precipitates along with genomic DNA could also cause suppression of PCR amplification [1], by improper priming of DNA templates. In recent years, molecular markers are increasingly being deployed due to study mutational changes. Among the different molecular markers, some are relatively cheaper and simple to use. One such marker is Random Amplified Polymorphic DNA (RAPD), which is a Polymerase Chain Reaction (PCR) based DNA marker. This assay is based on the amplification of genomic DNA with single primer of arbitrary nucleotide sequence [3]. RAPD is an inexpensive and rapid method, not requiring any information regarding the genome of plant, and has been widely used to ascertain the genetic diversity. It requires only small amount of genomic DNA and can produce high levels of polymorphism and may facilitate more effective diversity analysis in plants and it provides information that can help to define the distinctiveness of species and phylogenetic relationship. Various protocols are available for DNA extraction from plant species $[4,5]$ and they have been further modified to provide suitable DNA for several kinds of analyses [6,7]. The ultimate aim of this study to isolate genomic DNA and identify an optimum RAPD-PCR condition to screen Jatropha curcas and Gossypium hirsutum collected from metal containing waste dumps of magnesite and bauxite mines.

\section{Materials and Methods}

\section{Plant material}

The green house grown J. curcas and G. hirsutum was used for phytoremediation on waste dumps of magnesite and bauxite mines. Two grams of young fresh leaves were harvested from these plants for genomic DNA isolation.

\section{Reagent preparation}

An extraction buffer consisting of $2 \%$ CTAB (w/v), $0.5 \mathrm{M}$ Tris $\mathrm{HCl}$ pH 8, $0.5 \mathrm{M}$ EDTA $\mathrm{pH} 8,5 \mathrm{M} \mathrm{NaCl}, 0.2 \mathrm{~g}$ of poly vinyl pyrilodine (PVP), 3 M Sodium acetate solution ( $\mathrm{pH}$ 5.2), ribonuclease A (10 $\mathrm{mg} / \mathrm{ml}$ ), Chloroform: lsoamylalcohol (24:1), Phenol:Chloroform: Isoamylalcohol $(25: 24: 1 \mathrm{v} / \mathrm{v} / \mathrm{v})$, Ethanol $(70 \%, 100 \%)$ and TE buffer $(10$ $\mathrm{mM}$ Tris $\mathrm{HCl}$ and $1 \mathrm{mM}$, EDTA $\mathrm{pH} 8$ ) were prepared.

\section{DNA isolation protocol}

The modified CTAB method of Padmalatha and Prasad [8] was adopted for the isolation of genomic DNA. Freshly harvested leaf sample ( $2 \mathrm{~g}$ ) was ground in liquid nitrogen using a mortar and pestle along with $0.2 \mathrm{~g}$ of PVP [9]. The homogenized leaves were quickly transferred to $3 \mathrm{ml}$ of freshly prepared prewarmed $\left(65^{\circ} \mathrm{C}\right)$ extraction buffer and shaken vigorously by inversion to form slurry. The tubes were incubated at 65 to $68^{\circ} \mathrm{C}$ in a water bath for $60-80 \mathrm{~min}$ with intermittent shaking and swirling for every $30 \mathrm{~min}$. Equal volume of Chloroform: Isoamylalcohol (24:1) was added and mixed properly by inversion for $30 \mathrm{~min}$ and centrifuged at $12,000 \mathrm{rpm}$ for $15 \mathrm{~min}$ at room temperature to separate the phases. The supernatant was carefully removed and transferred to a new tube and an equal volume of icecold lsopropanol was added to form precipitation at $-20^{\circ} \mathrm{C}$ for a minimum of $30 \mathrm{~min}$. The samples were centrifuged at $12000 \mathrm{rpm}$ for $15 \mathrm{~min}$. The pellet was washed with $70 \%$ ethanol; air dried and resuspended

*Corresponding author: Narayanan Mathiyazhagan, Research scholar, Department of Biotechnology, Periyar University, Salem-11, Tamil Nadu, India, Tel: +91 9486502785; E-mail: mathimicro@gmail.com

Received July 15, 2011; Accepted December 10, 2011; Published December 12, 2011

Citation: Mathiyazhagan N, Natarajan D (2011) Optimization of RAPD-PCR Protocol to Screen Jatropha Curcas and Gossypium Hirsutum Grown in Metal Contaminated Soil. J Pet Environ Biotechnol 2:113. doi:10.4172/21577463.1000113

Copyright: (C) 2011 Mathiyazhagan N, et al. This is an open-access article distributed under the terms of the Creative Commons Attribution License, which permits unrestricted use, distribution, and reproduction in any medium, provided the original author and source are credited. 
in $3 \mathrm{ml}$ of TE buffer and $5 \mu \mathrm{l}$ of RNase was added and incubated at $37^{\circ} \mathrm{C}$. The genomic DNA was extracted with equal volumes of phenol: chloroform: 1soamylalcohol $(25: 24: 1, \mathrm{v} / \mathrm{v} / \mathrm{v})$ at $8000 \mathrm{rpm}$ for $15 \mathrm{~min}$. The aqueous layer was transferred to a fresh $15 \mathrm{ml}$ tube and extracted again with an equal volume of chloroform and lsoamyalcohol (24:1). The genomic DNA precipitated using equal volumes of absolute alcohol and $1 / 10$ th volume of sodium acetate at $-20^{\circ} \mathrm{C}$ for $30 \mathrm{~min}$ followed by centrifugation at $12,000 \mathrm{rpm}$ for $15 \mathrm{~min}$. The pellet was air dried and resuspended in TE buffer. All centrifugation steps were carried out at room temperature to obtain good quality of DNA without any impurities.

\section{Agarose Gel electrophoresis}

The concentration and purity of isolated DNA was determined by running the samples on $0.8 \%$ agarose gel based on the intensities of band when compared with the Lambda DNA marker. The nucleic acid concentration was calculated following the method of Sambrook et al. [10].

\section{Primer used}

Twenty primers from Operon Kit A (Operon - Medox -Bangalore, India) (OPA 01 to OPA 20) with $60-70 \%$ GC content were used (Table $1)$.

\section{Optimization of RAPD-PCR protocol}

The genomic DNA of J. curcas and G. hirsutum were amplified using RAPD-PCR. The amplifications were carried out in a MyGeneTM series Peltier thermal cycler Model MG 25+ (Long Gene Scientific instruments Co., Ltd). The various volume of samples $(2,3,5,10,20,30,50,75$ and $100 \mu \mathrm{l}$ of DNA templates), $\operatorname{MgCl} 2(1,2,3,4$, and $5 \mathrm{mM})$, dNTPs $(0.1,0.2,0.3$ and $0.4 \mathrm{mM})$; primer $(1,1.5,2,2.5,3$, 3.5, 4.0, 4.5 and $5.0 \mu \mathrm{l})$, Taq DNA polymerase (0.1, 0.5 and 1 unit) and the total reaction volumes $(14,16,18$ and $20 \mu \mathrm{l})$ were tested. The thermo cycler was programmed for an initial denaturation step of various min $(2,3,4$ and 5$)$ at $94^{\circ} \mathrm{C}$, followed by various number of cycles: 25,30 , $35,40,45$ and 50 cycles, and at various annealing temperature $(45,50$, $55,60,65$ and $70^{\circ} \mathrm{C}$ ) for $1 \mathrm{~min}$, extension was carried out at $72^{\circ} \mathrm{C}$ for $1 \mathrm{~min}$ and final extension at $72^{\circ} \mathrm{C}$ for $7 \mathrm{~min}$ and hold temperature of $4^{\circ} \mathrm{C}$ at the end. The amplified PCR products were electrophoresed on $1 \%(\mathrm{w} / \mathrm{v})$ agarose gels in $1 \mathrm{X}$ TBE Buffer at $50 \mathrm{~V}$ for $3 \mathrm{~h}$ and then stained with ethidiumbromide $(0.5 \mu \mathrm{g} / \mathrm{ml})$. Gels with amplification fragments were visualized and photographed under UV light. The intact Lambda DNA (DNA) was used as a marker throughout study.

\section{Results and Discussion}

The extraction of high quality and low polysaccharide genomic DNA from J. curcas and G. hirsutum taken from magnesite, bauxite and control soils was achieved. Peterson et al. [12] and Porebski et al. [13] stated that the presence of oxidizing agents (polyphenols), which are powerful compounds found in many plant species, can reduce the yield and purity by binding covalently with the extracted DNA making it useless for most research applications. Ziegenhagen and Scholz [7] reported some secondary metabolites (Tannins, terpenes and resins) are also difficult to separate from DNA and certain polysaccharides are known to inhibit RAPD-PCR. Many DNA isolation procedures also yield large amounts of RNA, especially $18 \mathrm{~S}$ and 25S rRNA $[2,14,15]$ from Gossypium species and J. curcas. Large amounts of RNA in the sample can chelate $\mathrm{Mg}^{2+}$ and reduce the yield of amplified products (Table 1) (Figures 1,2,3). A prolonged

\begin{tabular}{|c|c|c|}
\hline S.NO & Primers & Nucleotide sequence \\
\hline 1 & OPA-04 & 5'AATCGGGCTG3' \\
\hline 2 & OPA-13 & 5'CAGCACCCAC3' \\
\hline 3 & OPA-18 & 5'AGGTGACCGT3' \\
\hline 4 & OPA-07 & 5'GGTGACGCAG3' \\
\hline 5 & OPA-01 & 5'TTCGAGCCAG3' \\
\hline 6 & OPA-02 & 5'GTGAGGCGTC3' \\
\hline 7 & OPA-03 & 5'GGGGGTCTTT3' \\
\hline 8 & OPA-04 & 5'CCGCATCTAC3' \\
\hline 9 & OPA-05 & 5'GATGACCGCC3' \\
\hline 10 & OPA-06 & 5'GAACGGACTC3' \\
\hline 11 & OPA-07 & 5'GTCCCGACGA3' \\
\hline 12 & OPA-08 & 5'TGGACCGGTG3' \\
\hline 13 & OPA-09 & 5'CTCACCGTCC3' \\
\hline 14 & OPA-10 & 5'TGTCTGGGTG3' \\
\hline 15 & OPA-05 & 5'TGTTCCACGG3' \\
\hline 16 & OPA-07 & 5'CAGCGACAAG3' \\
\hline 17 & OPA-16 & 5'ТCTCCGCCCT3' \\
\hline 18 & OPA-18 & 5'AATGCGGGAG3 \\
\hline 19 & OPA-11 & 5'GTCCACTGTG3' \\
\hline 20 & OPA-02 & 5'CACAGCTGCC3' \\
\hline
\end{tabular}

Table 1: Oligonucleotide Operon primers (A series).

Lane 1 Lane 2 Lane 3 Lane 4 Lane 5 Lane 6 Lane 7

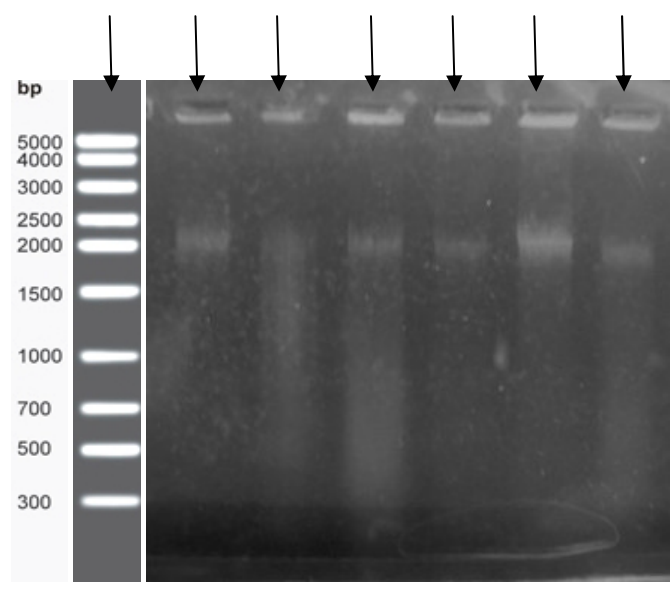

Figure 1: Isolation of plant DNA.

overnight RNase treatment degraded RNA into small ribonucleosides that do not contaminate the DNA preparation and yielded RNA-free pure DNA. Additional precipitation steps removed large amounts of precipitates by centrifugation and modified speed and time [11]. Almost all the tested parameters for RAPD-PCRs like the concentration of template DNA $3(\mu \mathrm{l})$, primer, magnesium chloride (3), Taq DNApolymerase (1), dNTPs (0.3) and temperature and time intervals during denaturation $(3.0 \mathrm{~min})$, annealing $(55)$ and elongation $\left(72^{\circ} \mathrm{C}\right.$ for $1 \mathrm{~min}$ and final extension at 72 for $7 \mathrm{~min}$ ) were also optimized, which also had an effect on amplification, banding patterns and 
Citation: Mathiyazhagan N, Natarajan D (2011) Optimization of RAPD-PCR Protocol to Screen Jatropha Curcas and Gossypium Hirsutum Grown in Metal Contaminated Soil. J Pet Environ Biotechnol 2:113. doi:10.4172/2157-7463.1000113

Page 3 of 4

reproducibility. The optimized conditions for RAPD-PCR protocol are given in Table 2. The size of the amplified fragments ranged from 480-3300 bp. The conditions described in the present work consistently amplified DNA fragments of plant species belonging to different genera with various medicinal and aromatic properties. Liu et al. [16] conducted RAPD 'fingerprinting' technique and detected genotoxininduced DNA damage of plants (barely) from heavy metal (Cd) contaminated soil and optimized the standard protocol. The present optimized protocol for DNA isolation and RAPD-PCR may serve as an efficient tool for further molecular studies. Padmalatha and Prasad [8] also reported that prolonged overnight RNase treatment to produce RNA-free pure DNA. Additional precipitation steps removed large amounts of precipitates (detergents, proteins and polysaccharides) by

Lane1 Lane 2 Lane 3 Lane 4 Lane 5

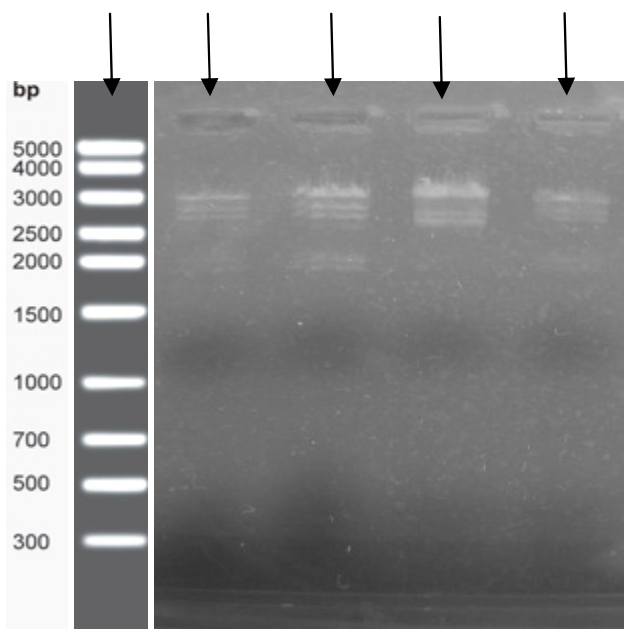

Figure 2: Amplification of Plant DNA by RAPD.

Lane 6 Lane 7

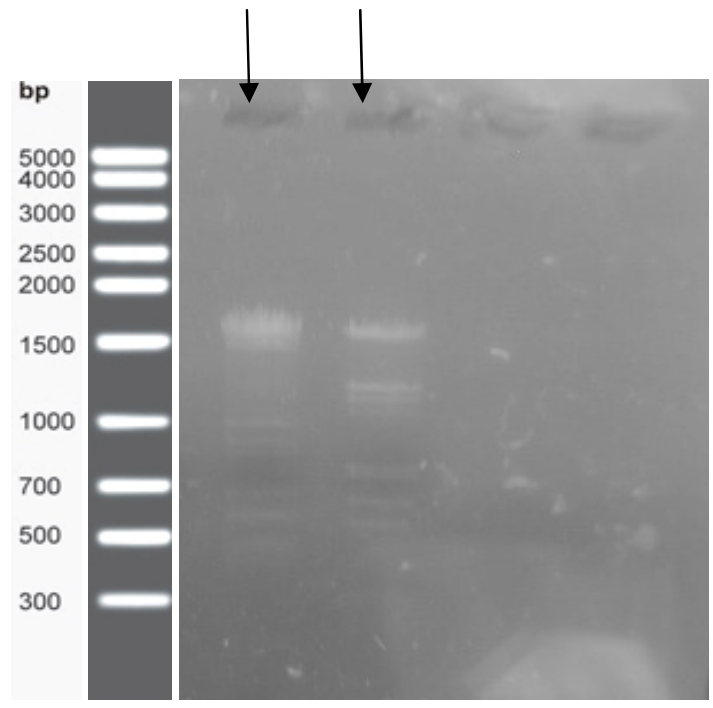

Figure 3: Amplification of Plant DNA by RAPD.

\begin{tabular}{|c|c|c|c|}
\hline PCR reagents & Tested range & $\begin{array}{c}\text { Optimum } \\
\text { range }\end{array}$ & Results of tested ranges \\
\hline $\begin{array}{c}\text { DNA } \\
\text { concentration } \\
(\mu \mathrm{l})\end{array}$ & $\begin{array}{l}2,3,5,10,20,30,50,75 \\
\text { and } 100\end{array}$ & 3 & $\begin{array}{l}\text { No amplified bands with } \\
\text { lower concentration and } \\
\text { presence of thinned band } \\
\text { at higher concentration } \\
\text { effected the repeatability }\end{array}$ \\
\hline $\begin{array}{l}\operatorname{MgCl}_{2}(\mathrm{mM}) \\
\operatorname{dNTPs}(\mathrm{mM})\end{array}$ & $\begin{array}{c}1,2,3,4, \text { and } 5 \\
0.1,0.2,0.3 \text { and } 0.4\end{array}$ & $\begin{array}{l}3 \& \\
0.3\end{array}$ & $\begin{array}{l}\text { Excess/lower concentration } \\
\text { increases the non specificity } \\
\text { and yield of the product. } \\
\text { Increased concentration } \\
\text { reduces the free } \mathrm{Mg}^{2+} \text {, } \\
\text { interfering with the enzyme. }\end{array}$ \\
\hline $\begin{array}{c}\text { Primer } \\
\text { concentration } \\
(\mu \mathrm{M})\end{array}$ & $\begin{array}{c}1,1.5,2,2.5,3,3.5 \\
4.0,4.5 \text { and } 5.0\end{array}$ & 2.5 & $\begin{array}{l}\text { Lower and higher } \\
\text { concentrations lead to } \\
\text { absence of amplification } \\
\text { and primer dimer formation, } \\
\text { respectively. }\end{array}$ \\
\hline $\begin{array}{c}\text { Taq } \\
\text { polymerase } \\
\text { (Units) }\end{array}$ & $0.1,0.5$ and 1.0 & 1 & $\begin{array}{l}\text { Lower concentration did not } \\
\text { show proper amplification. } \\
\text { High concentration showed } \\
\text { decreased specificity. }\end{array}$ \\
\hline $\begin{array}{c}\text { Initial } \\
\text { Denaturation } \\
\text { time interval } \\
(\mathrm{min}) \text { at } 94^{\circ} \mathrm{C}\end{array}$ & $2,3,4$ and 5 & 3.0 & $\begin{array}{l}\text { Higher/lower time intervals } \\
\text { (from optimum) leads to } \\
\text { reduction in amplification, } \\
\text { loss of Taq polymerase } \\
\text { activity and lack of } \\
\text { reproducibility }\end{array}$ \\
\hline Annealing ${ }^{\circ} \mathrm{C}$ & $\begin{array}{c}45,50,55,60,65 \\
\text { and } 70\end{array}$ & 55 & $\begin{array}{l}\text { Higher/lower } \\
\text { temperatures }\end{array}$ \\
\hline $\begin{array}{c}\text { Reaction } \\
\text { volume }(\mu \mathrm{l})\end{array}$ & $14,16,18$ and 20 & 16 & $\begin{array}{l}\text { Influences the cost of the } \\
\text { PCR ingredients and not } \\
\text { effective bands obtained }\end{array}$ \\
\hline $\begin{array}{l}\text { Number of } \\
\text { cycles }\end{array}$ & $\begin{array}{c}25,30,35,40,45 \\
\text { and } 50\end{array}$ & 30 & $\begin{array}{l}\text { The optimum cycles only } \\
\text { shows effectiveness for } \\
\text { amplification }\end{array}$ \\
\hline
\end{tabular}

Table 2: Optimization of the RAPD-PCR reaction for J. curcas and G. hirsutum from mine waste dumps.

centrifugation. DNA degradation and precipitations were avoided to some extent by carrying out all the steps at a perfect timing. We found that these modified steps are necessary to standardize and increase the quality and quantity of genomic DNA analyses of plants grown from metal contaminated soil.

\section{Conclusion}

From our findings we concluded that the optimized protocol for plant genomic DNA isolation and DNA amplification process with Universal operon primers (A-serious) are effective for screening the plants grown from the metal contaminated sites.

\section{Acknowledgement}

The authors wish to thank the Department of Biotechnology, Periyar University, Salem District, Tamil Nadu, India for a fellowship to the senior author.

\section{References}

1. Pikkart MJ, Villeponteau B (1993) Suppression of PCR amplification by high levels of RNA. Biotechniqu 14: 24-25.

2. Vroh Bi L, Harvengt A, Chandelier G, Mergeai P, Jardin Du (1996) Improved RAPD amplification of recalcitrant plant DNA by the use of activated charcoal during DNA extraction. J of plant bree 155: 205-206.

3. Weising K, Nybon M, Woilf K, Meyer W (1995) DNA finger printing in plants of fungi. Plant genet resour newslett 97: 3-39.

4. Doyle JJ, Doyle JL (1987) A rapid DNA isolation procedure for small quantities of fresh leaf tissue. Phytochem Bull 19: 11-15. 
Citation: Mathiyazhagan N, Natarajan D (2011) Optimization of RAPD-PCR Protocol to Screen Jatropha Curcas and Gossypium Hirsutum Grown in Metal Contaminated Soil. J Pet Environ Biotechnol 2:113. doi:10.4172/2157-7463.1000113

5. Ziegenhagen B, Scholz F (1993) A procedure for mini-preparation of genomic DNA from needles of silver fir (Abies alba Mill.). Plant Mol Biol Rep 11: 117-121.

6. Wang Y, Taylor DE (1993) A rapid CTAB DNA isolation technique useful for RAPD fingerprinting and other PCR applications. Biotechniques 14: 748-750.

7. Ziegenhagen B, Scholz F (1998) Methods for difficult plant species.In: karp A, Issac PG and Ingram DS (eds), Molecular Tools for screening Biodiversity Plants and Animals, Chapman and Hall, London 32-35.

8. Padmalatha K, Prasad MNV (2006) Optimization of DNA isolation and PCR protocol for RAPD analysis of selected medicinal and aromatic plants of conservation concern from Peninsular India. Afri J of Biotech 5: 230-234.

9. Sahasrabudhe A, Deodhar M (2010) Standardization of DNA extraction and optimization of RAPD-PCR conditions in Garcinia indica. Int J Bot 6: 293-298.

10. Sambrook J, Fritsch EF, Maniatis T (1989) Molecular cloning: A laboratory manual. Cold Spring Harbor Laboratory Press, Cold Spring Harbor, New York, USA.

11. Gurudeeban S, Ramanathan T, Satyavani K, Dhinesh T (2011) Standardization of DNA Isolation and PCR Protocol for RAPD Analysis of Suaeda sp. Asian JI of Biotech 3: 486-492.
12. Peterson DG, Boehm KS, Stack SM (1997) Isolation of milligram quantities of nuclear DNA from tomato (Lycopersicon esculentum), a plant containing high levels of polyphenolic compounds. Plant Mol Biol Rep15: 148-153.

13. Porebski S, Baily LG, Baum BR (1997) Modification of a CTAB DNA extraction protocol for plants containing high polysaccharide and polyphenol components. Plant Mol Biol Rep 15: 8-15.

14. Katterman FRH, Shattuck VI (1983) An effective method of DNA isolation from the mature leaves of Gossypium species that contain large amounts of phenolic terpenoids and tannins. Prep Biochem 13: 347-359.

15. Mohamad Abdulla Jubera BS, Janagoudar DP, Biradar RL, Ravikumar RV, Kot $S$ et al. (2009) Genetic diversity analysis of elite Jatropha curcas (I.) genotypes using randomly amplified polymorphic DNA markers. Karnataka J Agric Sci 22: 293-295.

16. Liu W , Yang YS , Li PJ , Zhou QX , Xie LJ et al. (2009) Risk assessment of cadmium-contaminated soil on plant DNA damage using RAPD and physiological indices. J Hazard Mater 30: 161: 878-883. 